\title{
A STUDY ON OPINIONS OF THEATRE STUDENTS ABOUT THE PLAY-TEXT CONVERTIBILITY DURING PRODUCTION*
}

\section{Özlem BELKIS ${ }^{1}$}

Hatice ŞAŞMAZ ${ }^{2}$

\begin{abstract}
Written text is the basis of dramatic theatre. Play scripts, while having philosophical, literary an deven historical attributes until the beginning of the 20th century, have been taken into account within the context of stage performance after the second half of the 20th century. Especially 1960s were the years when the sanctity of the text was broken. By re-writing through transformation via radically unique approaches and aesthetics, ispiring productions have been manifested. From this point on, the following questions can be directed: Where does the script stand within the applied area of theatre? How and to what extent can the text can be transformed? And what are the thoughts of performing arts students on the subject? The purpose of this research is to contribute to the discussion explained above, and within this context, examine and learn about the opinions and thoughts of the performing arts students on the place of the text, its convertibility within the field of application of theatre. The method of this study is qualitative data research and focus group interview has been used as one of the data collection tools of this method. Two focus group interviews were held with participants who were trained in Dramatic Writing, Acting and Stage Design and the interviews were analyzed separately by descriptive analysis and content analysis by two researchers. Findings of the study: All participants shared the same opinion regarding that the text of the play would be changed and transformed during the staging, but different opinions have been put forward as to what extent the text may be altered. Although the Performers and the Designer Participants took the text as the starting point, it is interesting that the Author Participants opposed to the participants taking the text as a starting point. The text is perceived differently, semantically and functionally within the context of specializations, while other areas do not taken into account in collective production. As a result, it may be suggested that studies should be undertaken to overcome sensitivities in the context of texts and that students should be directed to work in professional life to add other areas of collective production.
\end{abstract}

Key Words: Text, Focus group, Theatre education, Stage text, Playwriting education

\section{Introduction}

Written text is the basis of dramatic theatre and the starting point of performance. Everything on the stage is built on this ground. From ancient to the mid-20 theentury dramatic texts were considered as philosophical, linguistic, literary or even historical texts. But after mid-20 $0^{\text {th }}$ century dramatic texts have also been considered as sometimes the performance itself or sometimes only a springboard for brand new productions. Undoubtedly, the groundbreaking directors as Littlewood, Planchon, Mnouchkine, Grotowski, Brook, Stein, and Wilson have also made a major contribution to this improvement (Bradby and Williams, 1988, p.1-23). Actually the $20^{\text {th }}$ century is a period when

Dokuz Eylül University, Faculty of Fine Arts, Performing Arts; ozlem.belkus@deu.edu.tr

Düzce University, Faculty of Art, Design and Architecture, Performing Arts; haticesasmaz@duzce.edu.tr

*Part of this research on May 19-21, 2016, II. International Social Sciences Symposium (ASOSSCONGRESS) were presented as oral presentations. 
changed not only view at texts but also view at authorship. The concept of dramaturgy has reached its current meaning; the texts have started to be transformed or rewritten in the direction of the director's interpretation in this period as well (Turner and Behrndt). Additionally, the sanctity, the immunity and privacy of the text are broken during the 1960s. Within this context, Peter Brook's following statement is a striking approach that the text of the play can change in endless ways until it reaches the theatre audience: "-after all, the texts do not get burned-, each person can do what hethinks necessary with a text and still no one suffers. What is interesting is the result." (Brook, 1996, p. 100). When it comes to the 2000s, though, a textual understanding was reached in which a very different technique or form was used, with the effect of postmodern text editing to post-dramatic aesthetics from storytelling to writing the text with the body (Radosavljevic; Case).

Of course, all the major or minor text transforms in the productions are related to and based on dramaturgy, director's interpretation, and postmodern text readings. And of course every new production is / has every new point of view. The texts performing on scene (or elsewhere) can be called performance text, performing text, body-text, physical text, writing the text with the body, landscape text, paysage text, dramaturgic text, etc. Shortly, there is a fascinating metamorphosis in understanding dramaturgy from Lessing's HamburgisheDramaturgie to 'new dramaturgy' concept (Trencsényiand Cochrane) and then from there to 'new media dramaturgy' (Eckersall, Grehan and Scheer).

On the other side, from above all these things, the following questions can be thought: What is the infrangible position of the original text in the practice area of the productions? What do the authors of the original texts think about these changes / transformations? How and to what extent the text can be transformed? Interpretation and reproduction of the play text takes a prominent place in performing arts education. In this regard what are the approaches and opinions of the performing arts students in the context of these questions? What are their opinions on transformability of the original text and the area it covers in production?

The study aims to contribute to the questions above, and, within this context, examine and learn the opinions and thoughts of the performing arts students on the place of the original text, its convertibility within the field of production.

There are a lot of studies those focus on dramaturgy, director's working process or play text analyse from the director's or dramaturg's views. But there isn't a study that focuses on the place and the convertibility of the original play text in the theatre practice from the author's view. When we have a look into the relevant literature regarding the subject, we can see that there are studies on theatre history (Brocket and Hildy; Cohen; Russell), studies on theories of theatre (Carlson; Dukore; Clark), studies onplaywriting (Greig; Neipris; Smily; Dunne) and studies on dramaturgy (Eckersall, Grehan and Scheer; Romanska; Turner; Trencsényiand Cochrane; Turner andBehrnt; Luckhurst). The importance of this study can be defined at this point: trying to produce a discussing view on writer's and performing arts students' side.

\section{Method}

To learn opinions and thoughts about changing the play text and to ensure that ideas are expressed freely this study was carried out by qualitative data research method.

The qualitative research method has many definitions. It is possible to say that the qualitative method is an umbrella term containing many other sub-methods (ethnographic research, anthropological 
research, case study, phenomenological research, theory development, content analysis, etc.). Qualitative research also suggests that we should take a closer look at human thoughts and experiences as well as witnessing experimentation, thinking that objective reality is not fully understood by numbers or ratios. It sets out from the idea that there are multiple ways of exploring, comprehension, and understanding.

We conduct qualitative research because a problem or issue needs to be explored. This exploration is needed, in turn, because of a need to study a group or population, identify variables that can then be measured, or to hear silenced voices. These are all good reasons to explore a problem, rather than to use predetermined information from the literature or relyon results from other research studies. We also conduct qualitative research because we need a complex, detailed understanding of the issue. This detail can only be established by talking directly with people, going to their homes or places of work, and allowing them to tell the stories unencumbered by what we expect to find or what we have read in the literature (Creswell, 2016, p. 39-40.)

In this research, qualitative research method is used to investigate the students' ideasabout what the text is and how / how much it can be transformed in the production. For this reason, the participants were selected from the Performing Arts students of a state university. The focus group, which was chosen as data collection tool, consisted of 12 students who have successfully completed at least 5 terms. The focus group interview participants were selected on the basis of "they should have had experiences and express their experiences clearly" (Cresswell, 2016, p.150).For this reason, in order to build a focus group that is homogeneous and sensitive to differences, the participants were equally selected from three different programs (Dramatic Writing and Dramaturgy Program, Acting Program and Stage Design Program). The branches were divided equally and 2 groups consisting of 6 students were formed.

The interviews were held 21-25.04.2017. In order to capture a totally neutral atmosphere, interview locations were chosen accordingly where none of the participants have ever been before. The following two fundamentals and probation questions were asked to the participants to support these core questions:

- What is the text and how is described its rolein the practice area of theatre?

○ What do you understand from "text"?

- Could you explain what kind of emphasis and importance the text has in the stage practice?

- Why does the text vary in stage practice and what kind of transformation is this?

- What contexts or items of text do you think should be inconvertible/ inviolableHow different can the text be moved from the author's conception?

- When you first meet a text to work on, what are the first items you pay attention?

- When you receive a text to work on, what are your thoughts regarding the transformation of the text? 
For analysis of the data,focus group interviews were recorded and deciphered, and both researchers performed separate content and descriptive analysis, therefore, the reliability and validity framework of the research has been checked. The interviews were transferred to Nvivo for Mac 11.2.2., and coding and theme groups are parsed in the program.

Some considerations regarding the methodology and research framework for this research have been set. For example, it is assumed that students will participate in focus group discussions voluntarily, sincerely and in a correct way.

Like every research, this research has some limitations. It should, primarily, be noted that findings from the study can only be generalized to groups similar to those in the study. It should be noted that the experience and opinions expressed in the context of the pupils are specifically targeted, and that the debate is intended to contribute to the performing arts education. Within this framework, the population/sampling of the research is not seen as a limitation in the context of the subject.

\section{Findings And Comment}

Participants of the research will be referred to as Author Participant, Performer Participant and Designer Participant while the findings are quoted.

First of all, there is a point, which must be explained. Although all participants had been given equal duration of conversation during the focus group discussion, an imbalanceoccurred in the way they were putting forward their opinions. The expertise areas of the participants, who share their thoughts in a limited way, are overlapping. $49 \%$ of the total interview content is owned by the Author Participants, $40 \%$ by the Performer Participants and $11 \%$ by the Designer Participants. It can be considered that this distribution is a natural outcome and that individuals working on the writing act already produce more ideas within this framework.

The findings were coded in the framework of basic interview questions, which were formed in parallel with the research questions, and the themes were formed within this context. Within this context, the findings were collected under two headings:

- Opinions on the text and the place of the text in practice area of the theatre.

- Opinions about the change of the text in the production process.

It should be noted that the findings are categorized according to their majors and the findings are significantly different from the areas of expertise.

\section{Opinions on the text and the place of the text in practice area of the theatre}

Participants responded to the questions by centralizing their majors. This is a very inherentand expected approach.It is expected and preferred that all the participants answer by means and on behalf of their own profession branch of the field.. This finding is very striking, because the importance of collectivism and working together is emphasized insistently in each step of performing arts education. In addition, in the department where the research is conducted, the common courses of all three branches constitute nearly $35 \%$ of the annual curriculum except for the branch lessons. 
While participants were responding the questionsIt was observed that, Author and Performer Participants gavemuch more clear answers than Designer Participantsabout what the text is. This finding can be thought that playwriting and acting students are thinking and studying much more text-focused than stage-design students.

In general it can be said that Performer Participants and Designer Participants have defined the text as a starting point or a stepping-stone. In contrast, Author Participants have described the text in a more philosophical and literary context:

Sometimes it is a committed starting point; sometimes it is a starting point that can produce everything other than itself. (Performer Participant 1)

Text is the starting point something that will give you a spark... I think it should be transformed; this is why the audience goes to see Romeo Juliet, Richard III many times. (Designer Participant 2)

A text is the world created by the author. (Author Participant 1)

These are the questions the playwright brings forward... asking some questions and running after those questions; this is a way of thinking for me ... (Author Participant 2)

The Performer and the Designer Participants have stated that the text is a starting point or a general canvas for the play to be or already staged. All of the Performer participants share the same idea in this regard. When we look at the Designer Participants' points of view, we can see that the text is described as a starting point; but they are strongly emphasized that an effective and accurate text analysis should be done for sustaining the relationship between the author's text and the play on the stage. Half of the Author Participants did not agree with the other participants that the text of the play was a starting point or an outline for the play to be staged. All the Author participants accept that the text can be changed and transformed during the staging phase and is open for interpretation and rewriting. However, two Author Participants did not share the idea that the text was just a starting point.

I define the text as a work of art rather than a starting point. (...) For instance, when one writes a novel, nobody says, "this novel is a starting point. Now, I will take this novel and re-write it properly and publish". (Author Participant 1)

If we assess the text in terms of the related concepts with the descriptions and expressions, The Author Participants defined the text on the basis of the concepts of author and story; Performer Participants on the basis of action, Designer Participants on the basis of analysis.

While defining the text, the Author Participants separated the text written by the author from the stage text and they had mutual opinion on this. The Performer Participants and the Designer Participants did not make any such differentiation and, they meant and understood the text of the staged production when a "text" is mentioned.

At this point we have to make a distinction between stage text and text. ... The text becomes meaningful with the stage performance, but the thing carried over in centuries is not the same stage performance of that night. This is interesting; that is, the thing that is important at the moment when the art action takes place is not the text but the performance. However, when I turn back to evaluate that work of art in centuries, the important thing is the text, itself. (Author Participant 2) 
The literary value and meaning of the text is also discussed during the focus group meetings. The Author Participants have emphasized that the text reaches significance when it is staged; but it also has an integrity and meanings even when it is not produced. The Performer Participants emphasized that they did not agree with this view and expressed that the text cannot produce meaning if it is not staged.

The participants were asked the question of "what kind of weight and importance the text has in performance?" The Designer Participants thought that the overall value of the text on the stage was $50 \%$ of the overall construction and the Performer Participants thought it was 35\%. The Author Participants noted that they did not make such a differentiation, the area covered by the text on the stage was variable, it even that existed at all phase of the play.

\section{The change of the play -text in the process of adopting to stage}

For the findings obtained in this context, it can be said that the Performer and Designer Participants provided the idea consensus, and the Author Participants divided into two separate opinions. Performer and Designer Participants have come to anagreed opinion that the text of the play can change in many ways on the stage, that it can be rewritten within this framework, and even, it should be like this.

I take it as a starting point, a stepping-stone and I transform it to any language I wish. When I say language, I do not mean the spoken language, of course, but the language of movement, dance or anything. (Performer Participant 2)

Apart from what the author wants to tell us, I think the play should be open to change and transformation... I think many changes can be applied, except the prerequisite situations. (Performer Participant 4)

With regard to the change of the text in the producing process, the Designer Participants thought that the text could be changed in line with the interpretation and re-writing of it, if necessary. Participants in this group emphasized the importance of analysis process of the text, indicating that rewriting would only be possible, if necessary, as the result of this analysis. When expressing the views of the participants in this group, they always pointed out that the text should be taken as basis and action should be taken by considering the analysis on the text. At the other hand what the Designer Participants grasped from the change in the staging process of the text is that are, mostly, the arrangements within the line and dialogues.

With regard to the change during the producing process of the text, half of the Author Participants stated that they could be free to change the text and the other half explained that they did not find it right to transform the text to a completely different direction from the imagination of the author.

Generally speaking, all three groups agreed that the text could be changed more or less in the process of staging; it might be rewritten partially or completely. In short, all participants agreed that the text of the play would be transformed for performance. The issue discussed and disagreed here is that, to whatextent willthis change, and transformation take place. The most talked-about and debated topic during negotiations is not whether the text of the play will change or not; but the rate of the extent of the change. Within this context, the participants were asked what were the elements that cannot be changed in the text. The general approach, as one participant has stated, is that "the unchangeable element of each text varies from text to text" (Author Participant 2). 
When we look into the findings of the research as a whole, it is seen that the text has different meanings and functions for the participants in all three groups. This difference can be viewed as a natural approach, but it requires to be discussed.

\section{Results And Discussion}

Changing text according to the interpretation during staging, in other words dramaturgical writing, is a normal and exciting process. There are really very creative productions in very different concepts. This framework is the consequence of post-1960 creative dramaturgical collaboration between directors, dramaturgs and other creative components.

It may be useful to focus and think on this pre-acceptance from a different perspective. We prepared questions that we could use as tools to think about text and production. And we asked the questions to a focus group consisting performing arts students. How is the text defined? What is the place of the text in the practice area of the theatre? How and to what extent can the text be changed during staging process? The questions can of course be varied.

It was exciting that the focus group consisted students, because they all exhibited fervent and radical approaches, despite the learning of collectivism, which is a requirement of theatricality in the performing arts education. There are, of course, various definitions and boundaries of the text of a play and of the process of change that the production has undergone. These are taught both in practical and theoretical courses and in workshops in performing arts education. What are the individual's thoughts who will be professional theatre performers of your near future about the play text and its change in the production? These thoughts can also provide us with an area of thinking, a discussion on the performing arts education.

When we look into the findings of the research in general, it appears that the views of participants in the context of their expertise seem to correspond. It was found out that the professional views of the Designer and Performer Participants are generally similar to each other, while the Author Participants have a different point of view. It is natural that people of every field of profession think and focus on behalf of their side. However, it is beneficial to advance to the common points with other creative areas for collective art productions such as theatre. This conclusion suggests a possible unilateralism in artistic creation, and it may be considered to increase the opportunities for collaborative work in in-service implementations. What we are implying to here is not an empathy-based approach. in a training where Playwriting, Stage Design and Performing come together under one roof, more collaborative fields can be created and students from different fields can be encouraged to work and produce together more. What is the reason to origin of the different thoughts of the students? Is it just because they study and produce in different areas?

It is evident from the findings that there is a sharp divergence in the way participants, who are still getting performing arts training, approach and look at the text. For example, while the author gives more focus on sophisticated story definitions, the performer approaches more on action on the stageThe solution-oriented and impact-driven approaches of the Performer and Designer Participants attract attention. This approach, on the one hand, paves the way for the Performer and Designer Participants and leads them to creativity. On the other hand, it was observed that the fact that changes in the text might cause copyright problems were overlooked. We can suggest that the copyright and the immunity of the work should be considered, during the in-service training. It is also clear that there are certain sensitivities to the possible changes that the text will experience 
during the staging process. It may be suggested that discussions and joint workshops be created to overcome these sensitivities in the in-service training.

The thing called as text may have a simple dictionary definition, but, in fact, it does not have a real, single definition. Within the context of theatre art, the 'text' is understood in different ways and in different contexts and is seen in a framework that is reproduced to allow for other creativities. As a researcher it is an honor and duty to contribute to the practice area and be as enthusiast as the participants of this study.

\section{References}

Barba, E. and Savarese, N. (1991). A Dictionary of Theatre Anthropology, The Secret Art of the Performer(Richard Fowler,Trans.). London and New York: Routledge.

Bradby, D. and Williams, D. (1988).Director's Theatre. Hong Kong: Macmillan.

Brockett, O. G. and Hildy, F. J.(2008). History of The Theatre. Boston: Pearson Education Inc.

Brook, P. (1996). A Book About the Theatre; Deadly, Holy, Rough, Immediate: The Empty Space. New York: Simon $\S$ Schuster.

Carlson, M. (1984). Theories of the Theatre: A Historical and Critical Survey, From the Greeks to the Present. Ithaca and London: Cornell University Press.

Case, S-E. (2008). Feminism and Theatre. The United States: Palgrave Macmillan.

Clark, B. (1965). European Theories of the Drama. New York: Crown Piblishing.

Cohen, R. (1988).Theatre. Texas: Mayfield Publishing.

Creswell, J. (2016).Qualitative Inquiry and Research Design: Choosing Among Five Approaches. USA: Sage Publications.

Dukore, B. F. (1974).Dramatic Theory and Criticism - Greeks to Grotowski. New York, San Francisco, Atlanta, Montreal, Dallas, Toronto: Hold, Rinehardt and Winston Inc.

Dunne, W. (2009).Tools To Develop Characters, Cause Scenes, And Build Stories - The Dramatic Writer's Companion. Chicago and London: The University of Chicago Press.

Eckekrsall, P. and Grehan,H.and Scheer,E. (2017). New Media Dramaturgy - Performance, Media and New Materialism. London: Palgrave Macmillan.

Greig, N. (2005). Playwriting, A Practical Guide. London and New York: Routledge.

Luckhurst, M. (2006). Dramaturgy: A Revolution in Theatre. United Kingdom: Cambridge University Press.

Neipris, J. (2005). To Be A Playwright. New York and London: Routledge.

Piscator, E. (1980). Political Theatre. Trans. with chapter introductions and notes by H. Roddison. Eyre Methuen. 
Radosavljević, D. (2013). Theatre-Making, Interplay Between Text and Performance in the 21st Century. New York: Palgrave Macmillan.

Romanska, M. (2015). The Routledge Companion to Dramaturgy. New York: Routledge.

Russell, A.D. (1987).Period Style For The Theatre. New Jersey: Prentice Hall Publishing.

Sart, G. (2015). Fenomenoloji ve Yorumlayıc1 Fenomenolojik Analiz Phenomenology and Phenomenological Analysis. N. F. Seggie and Y. Bayyurt, (Ed.),In TheNitel Araştırma (Qualitative Inquiry)(1st ed.) (70-81).Ankara: Pegem Akademi.

Smiley, S. (2005).Playwriting - the Structure of Action. New Heaven and London: Yale University Press.

Trencsényi, K. and Cochrane,B. (2014). New Dramaturgy - International Perspectives on Theory and Practice. London, New Delhi, New York, Sidney: Bloomsbury Methuen Drama.

Turner, C. and Behrnt,S. K. (2008). Dramaturgy and Performance. New York: Palgrave Macmillan.

Turner, C. (2015). Dramaturgy and Architecture - Theatre, Utopia and the Built Environment. New York: Palgrave Macmillan.

Wang, C. L. (2008). Entrepreneurial orientation, learning orientation, and firm performance. Entrepreneurship theory and practice. 32(4), 635-657. 